๑ Open Access Full Text Article

CORRIGENDUM

\title{
Inhibition of Proliferation and Migration of Tumor Cells Through Phenylboronic Acid-Functionalized Polyamidoamine-Mediated Delivery of a Therapeutic DNAzyme DzI 3 [Corrigendum]
}

\author{
Yang J, Zhang J, Xing J, Shi Z, Han H, Li Q. Int $J$ \\ Nanomedicine. 2019;14:6371-6385. \\ The authors have advised that during the assembly of sub- \\ figures in the preparation stage of the manuscript, two images \\ in each of the Figure S8 and Figure S9 were duplicated.
}

On page 6380, supplementary Figure S8, image CalceinAM, Dz13 and Calcein-AM, PP/Dz13 were duplicated.
On page 6380, supplementary Figure S9, images a and b were duplicated.

The revised Figure S8 and Figure S9 on page 6380 in the supplementary link should be presented as follows. 


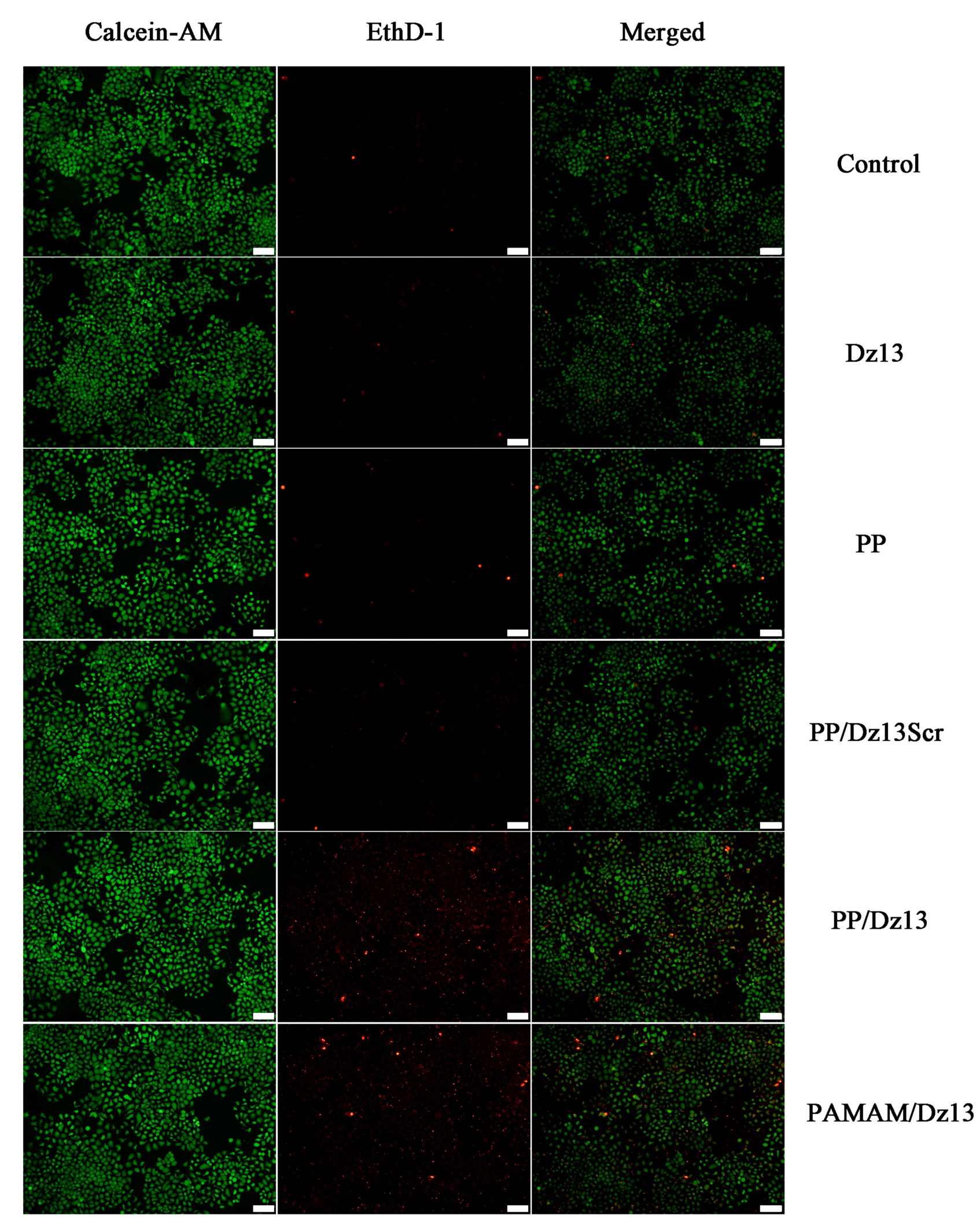

Figure S8. The live/dead staining of HepG2 cells after the transfection with different nanoparticles. The scale bar is $100 \mu \mathrm{m}$. 

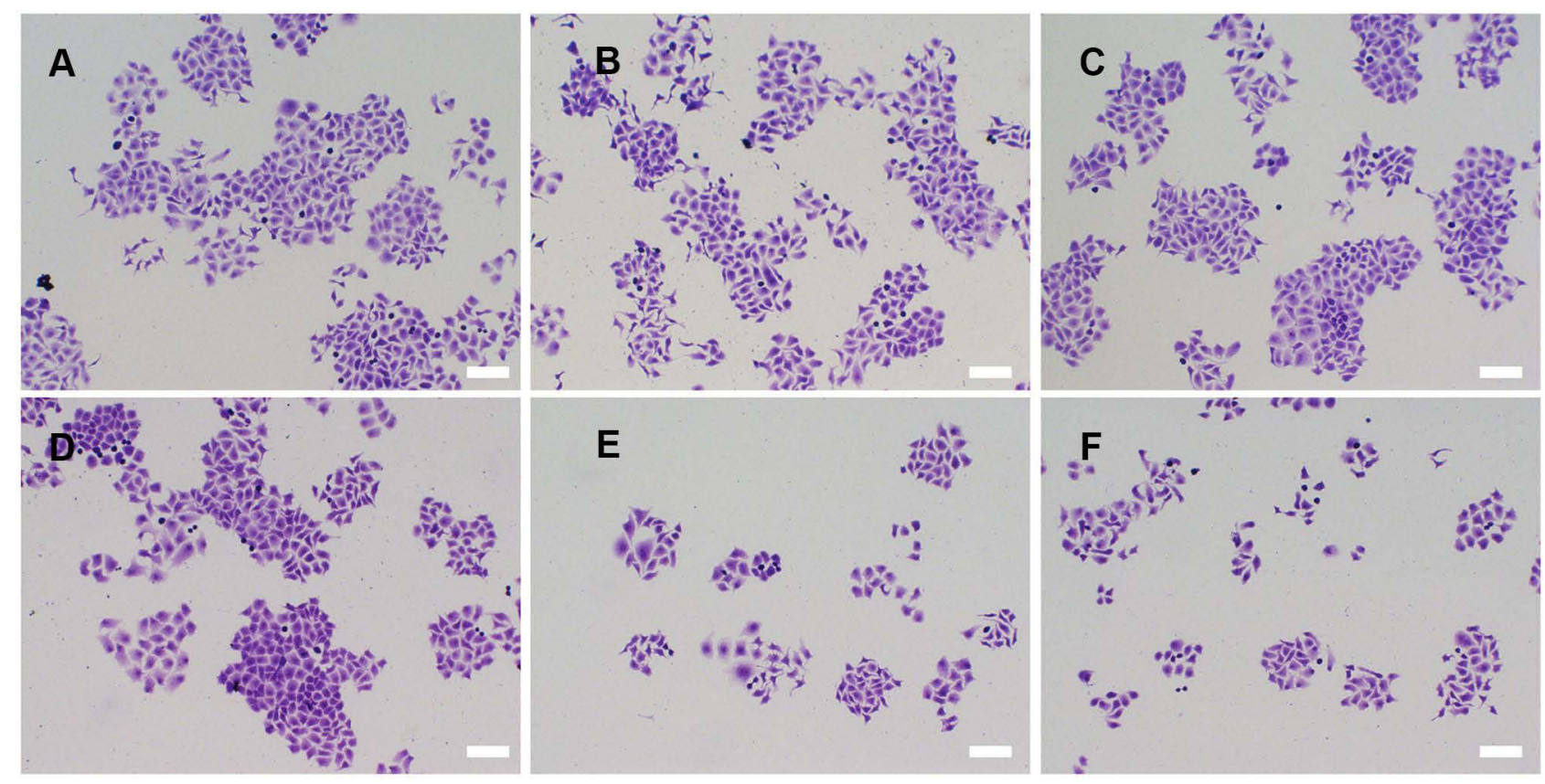

Figure S9. The colony formation assay of HepG2 cells transfected with different nanoparticles: (A) control, (B) Dz/3, (C) PP, (D) PP/Dz/3Scr, (E) PP/Dz/3 and (F) PAMAM/DzI3 nanoparticles. The scale bar is $100 \mu \mathrm{m}$.

\section{Publish your work in this journal}

The International Journal of Nanomedicine is an international, peerreviewed journal focusing on the application of nanotechnology in diagnostics, therapeutics, and drug delivery systems throughout the biomedical field. This journal is indexed on PubMed Central, MedLine, CAS, SciSearch ${ }^{\mathbb{B}}$, Current Contents ${ }^{\mathbb{B}} /$ Clinical Medicine,
Journal Citation Reports/Science Edition, EMBase, Scopus and the Elsevier Bibliographic databases. The manuscript management system is completely online and includes a very quick and fair peer-review system, which is all easy to use. Visit http://www.dovepress.com/ testimonials.php to read real quotes from published authors. 